\title{
Evaluation of the Relationship Between Malocclusion and the Periodontal Health, Caries, Socio-economic Status of Children
}

\author{
Çocuklarda Görülen Malokluzyonlar ile Periodontal Sağlık, \\ Diş Çürükleri ve Sosyo-ekonomik Durum Arasındaki Illişkinin \\ Değerlendirilmesi
}

\author{
(D) Esra Öz, (D) Çiğdem Küçükeşmen
}

Süleyman Demirel University Faculty of Dentistry, Department of Pedodontics, Isparta, Turkey

Keywords

CPITN, DMFT, malocclusion, orthodontic treatment need

Anahtar Kelimeler

CPITN, DMFT, maloklüzyon, ortodontik tedavi ihtiyacı

Received/Geliş Tarihi : 04.02.2018

Accepted/Kabul Tarihi : 28.04.2018

doi:10.4274/meandros.galenos.2018.63835

Address for Correspondence/Yazışma Adresi: Esra Öz MD,

Süleyman Demirel University Faculty of Dentistry, Department of Pedodontics, Isparta, Turkey

Phone : +90 5326788040

E-mail : esrakaraagac@sdu.edu.tr

ORCID ID: orcid.org/0000-0002-5160-7211

(C) Meandros Medical and Dental Journal, Published by Galenos Publishing House.

This is article distributed under the terms of the

Creative Commons Attribution NonCommercial 4.0

International Licence (CC BY-NC 4.0).

\begin{abstract}
Objective: In this study, it was aimed to evaluate the relationship between malocclusions and various factors such as periodontal treatment needs, dental caries, anterior segment crowding and parental socio-economic status of 12-14 year-old children.

Materials and Methods: Classification of malocclusions of 534 patients aged 12-14 years who applied to our clinic in our study was done according to Angle malocclusion classification. Periodontal treatment requirements were assessed using community periodontal index of treatment needs (CPITN); dental caries were evaluated by decay, missing, filled teeth (DMFT). Statistical analysis was performed in SPSS Statistics Version 12.0 software package. $\mathrm{P}<0.05$ was considered statistically significant.

Results: The mean DMFT score of the children in the study group was $4.318 \pm 3.14$. The most common malocclusion was class 1 malocclusion (55.1\%). The differences between mean DMFT scores and malocclusion classifications were not statistically significant $(\mathrm{p}>0.05)$. According to the CPITN, individuals with healthy periodontal disease (CPITN 0) accounted for $24.9 \%$ of patients. It was seen that only $6.4 \%$ of the patients without anterior segment crowding had CPITN 2 score. It was observed that the CPITN 0 score decreased as the anterior segment crowding increased. It was found that the correlation between CPITN scores and anterior segment crowding was statistically significant $(p<0.05)$. However, the relationship between malocclusion classifications was not statistically significant $(p>0.05)$. There was no statistically significant relationship between parental socio-economic status and malocclusion classifications of children ( $p>0.05)$.

Conclusion: In our study, there is no correlation between malocclusions and dental caries. However, it has been observed that the lower anterior segment crowding are detrimental to periodontal health, laying the groundwork for the development of periodontal diseases. Oral health care and early interventions (preventive and preventive programs) are thought to help prevent orthodontic problems that can occur.
\end{abstract}


Öz

Amaç: Bu çalışmada, 12-14 yaşları arasındaki çocuklarda maloklüzyonların periodontal tedavi gereksinimleri, diş çürükleri, ön segmentte yer darlığı ve ebeveynlerin sosyoekonomik durumları gibi birçok faktörle olan ilişkilerinin değerlendirilmesi amaçlanmıştır. Gereç ve Yöntemler: Çalışmamızda, kliniğimize başvuran 12-14 yaşları arasındaki 534 sağlıklı hastanın malokluzyonlarının sınıflandırılması Angle malokluzyon sınıflamasına göre yapılmıştır. Periodontal tedavi gereksinimleri toplumda periodontal tedavi gereksinimi indeksi (CPITN), diş çürükleri çürük, kayıp, dolgulu dişler (DMFT) indeks değerleri kullanarak değerlendirilmiştir. İstatistiksel analizler SPSS Statistics Version 12 paket programında yapılmıştır. $\mathrm{P}<0,05$ istatistiksel olarak anlamlı kabul edilmiştir.

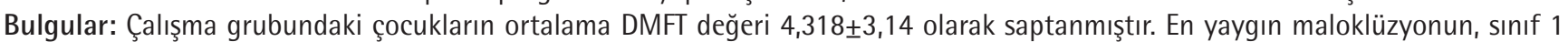
malokluzyon $(\% 55,1)$ olduğu görülmüştür. Ortalama DMFT değeri ile maloklüzyon sınıflamalarının arasındaki farklılıklar istatistiksel olarak anlamlı bulunmamıştır ( $p>0,05$ ). CPITN'e göre, sağlıklı periodonsiyuma (CPITN 0) sahip olan bireyler hastaların \%24,9'unu oluşturmuştur. Ön segmentte yer darlığı olmayan hastaların sadece \%6,4'ünün CPITN 2 değerine sahip oldukları görülmüştür. Ön segmentte yer darlığı artıkça CPITN 0 değerinin azaldığı gözlenmiştir. Ön segmentte yer darlığı ile CPITN değerleri arasındaki ilişkinin istatistiksel olarak anlamlı olduğu görülmüştür $(p<0,05)$. Ancak maloklüzyon sınıflamaları arasındaki ilişki istatistiksel olarak anlamlı bulunmamıştır $(p>0,05)$. Ailelerin sosyo-ekonomik seviyeleri ve çocukların maloklüzyon sınıflamaları arasında da istatistiksel olarak anlamlı ilişki bulunmamıştır ( $p>0,05)$.

Sonuç: Çalışmamızda, malokluzyon ile diş çürükleri arasında ilişki görülmemiştir. Ancak, alt ön dişlerdeki çapraşıklıkların, periodontal sağlık üzerinde zararlı etkileri olduğu, periodontal hastalıkların oluşmasına zemin hazırladığı gözlenmiştir. Ağız sağlığı bakımları ve erken yaşlardaki müdahalelerin (koruyucu ve önleyici programlar) oluşabilecek ortodontik problemlerin önlenmesine yardımcı olabileceği düşünülmektedir.

\section{Introduction}

Malocclusion is defined as the absence of an association between the upper and lower arches and abnormal alignment of the teeth. It has led to an increased interest in orthodontic treatment in many countries. Malocclusion can increase the risk of dental trauma, caries, periodontal problems, and oral dysfunctions such as chewing, swallowing, and talking difficulties (1).

Many factors can affect the severity of malocclusion and the desire to receive orthodontic treatment in individuals. One of these factors is the socioeconomic status of the patients/parents (2). Studies have shown that the incidence of malocclusion severity and orthodontic treatment need is high among individuals with low socio-economic status (3$5)$. The lack of social protection programs in the low socio-economic classes has been reported to be one of the main causes. In addition, high caries rates and the early loss of primary teeth, which may result from irregular dental visits, can cause the displacement of teeth and crowding $(5,6)$.

One of the most common types of malocclusions that affect the aesthetic appearance, function, and quality of life of the patients is dental crowding (1). Irregularities are generally observed $40-58 \%$ in the lower incisors in retention areas, especially in individuals with poor oral hygiene habits. In these areas, plaque accumulation can increase and caries occur, this affects periodontal health negatively (712). When malpositions with adverse effects are observed, orthodontic treatment should be provided to redirect occlusal forces. Consequently, occlusal trauma, which may also affect periodontal health, can be prevented.

Several epidemiological studies have been conducted in communities with different ethnic origins to evaluate the effects of malocclusion on periodontal health $(1,13,14)$. However, there are limited studies evaluating the relationship between malocclusion and the socio-demographic factors, caries, and periodontal status of children/adolescents in Turkey (10). These studies are important for evaluating the risk of caries in patients, identifying malocclusion and patients who require early preventive orthodontic treatment, and initiating treatments. Furthermore, the findings can be applied to improve oral hygiene in communities and reduce the costs of orthodontic treatment.

With more detailed information from this study results, we expect to identify malocclusion prevalence and associated conditions of malocclusion in 12-14-years-old children. This might help in understanding maloclussion occurrence and also assist public health interventions.

This study was designed to determine the relationship between malocclusion and the periodontal treatment requirements, dental caries, 
anterior segment crowding, and parental socioeconomic status of 12-14 year-old children. Our hypothesis was that malocclusion was associated with these parameters.

\section{Materials and Methods}

Required approvals from the Süleyman Demirel University Faculty of Medicine Clinical Studies Ethics Council were obtained for this study (approval number: 2014/93). The patients signed an Informed Consent Form, as established by the ethical guidelines. The study population consisted of 534 healthy children (233 males, 301 females) between 12 and 14 years of age who applied to our clinic in the period of June to December, 2014. It has been noted that individuals participating in the study were selected to have no orthodontic treatment history in the past, to be individuals with no syndromes that would affect the development of craniofacial structures, to have no orthognathic surgery, and not to be disabled individuals.

To evaluate the incidence of dental caries among the children, the number of decayed, missing, and filled teeth were recorded according to the decay, missing, filled teeth (DMFT) system (15). Angle's malocclusion classification was used to assess molar relationship (16). In order to determine the relationship between socio-economic status and malocclusion classification, the self-reported monthly income levels of the families were divided into three groups: <1000も, 1000-3000も, and >5000も. The lower and upper anterior segment crowding was assessed as follows: 0 - if there is no space; 1 - if only one segment is scored; 2 - if both segments are scored (17). To determine periodontal status and treatment needs, community periodontal index of treatment need (CPITN), which is recommended by the World Health Organization (WHO), was used. The highest score was recorded for each tooth according to the CPITN criteria. The highest score was selected as the CPITN score of each individual, and periodontal treatment needs were determined. The CPITN scores were set so that $0=$ healthy, $1=$ bleeding on gentle probing, 2 =calculus or other plaque-retentive factors, $3=$ shallow pocketing of 4-5 $\mathrm{mm}$, and $4=$ deep pockets of $6 \mathrm{~mm}$ or more (18).

\section{Statistical Analysis}

The data were analyzed using SPSS for Windows (SPSS-Statistical Package for Social Science, Software
Version 12, SPSS Inc., Chicago, IL, USA). The effects of CPITN score on crowding in the anterior segment and malocclusion classification were examined using the chi-square test. In addition, the chi-square test was used to evaluate malocclusion classification according to age, gender, socio-economic status, and DMFT scores. The Kruskal-Wallis test was used to evaluate the data obtained from the DMFT in terms of age. Student's t-test was used to analyze data on DMFT characteristics according to gender. Levels of statistical significance were set at $p<0.05$.

\section{Results}

In the study, 534 children between 12 and 14 years of age were evaluated. The mean age of the children was $13.01 \pm 0.04$. The distribution of patients according to age was as follows: 12 years, $170(31.8 \%) ; 13$ years, 189 (35.4\%); 14 years, 175 (32.8\%). There was no difference in the sex distribution of all age groups.

The mean DMFT score was 4.32 \pm 3.14 . In addition, $12.2 \%$ of the study group consisted of children with a DMFT score of 0 . The mean DMFT scores were $3.61 \pm 2.66$ for 12 -year-old children, $4.46 \pm 3.06$ for 13 -years-old children, and $4.86 \pm 3.52$ for 14 -year-old children; the scores were increased with age. Although the mean DMFT score of females $(4.39 \pm 3.16)$ was higher than that of males $(4.23 \pm 3.11)$, the differences between gender and the mean DMFT scores were not statistically significant ( $p>0.05$ ).

In the study, class 1 malocclusion (55.1\%) was the most common malocclusion. Class 2 (23\% class 2 div 1, 13.7\% class 2 div 2) was observed in $36.7 \%$ of the children, and class 3 malocclusion was observed in $8.2 \%$ of the children. The lowest mean DMFT scores were found among children with class 2 div 2 malocclusion, whereas the highest scores were found among children with class 1 and class 3 malocclusions. Class 1, class 2 div 1, and class 2 div 2 malocclusions were more common among females than males, whereas class 3 malocclusion was more common among males. There was no statistically significant relationship between gender and malocclusion ( $>0.05)$ (Table 1). Moreover, the relationship between age and malocclusion classification was not statistically significant ( $p>0.05)$. The differences between mean DMFT scores and malocclusion classification were not statistically significant $(p>0.05)$ (Table 2). 
The majority of children (83.14\%) had low-income families (<1000も, 1000-3000も). In the study, 62.2\% of the children with a monthly family income level of $3000^{\prime \prime}$ or more had class 1 malocclusion, and $2.2 \%$ had class 3 malocclusion. There was no statistically significant relationship between the socio-economic levels and malocclusion classification of children ( $p>0.05$ )

According to the CPITN, children with healthy periodontal status (CPITN 0) accounted for $24.9 \%$ of the study group. Despite the absence of calculus and iatrogenic irritation, there was bleeding (CPITN 1 ) in $67 \%$ of the patients during scaling, and both iatrogenic irritation and supragingival/subgingival dental plaque (CPITN 2) were observed in $8.1 \%$ of the patients. Patients with CPITN 3 and CPITN 4 were not evaluated.

Only $6.4 \%$ of the patients without anterior segment crowding had CPITN 2 score. CPITN 0 score were decreased with increasing crowding in the anterior segment. The relationship between CPITN scores and crowding was statistically significant in the anterior segment $(p<0.05)$ (Table 3$)$. In the study, $55.8 \%$ of children with CPITN 2 and $54.8 \%$ of those with CPITN 0 had class 1 malocclusion. It was found that only $8.67 \%$ of children with class 2 malocclusion required oral and dental care education as well as scaling. The relationship between CPITN scores and malocclusion classification was not statistically significant $(p>0.05)$ (Table 4).

\begin{tabular}{|c|c|c|c|c|c|c|c|c|c|c|}
\hline \multirow{3}{*}{ Gender } & \multicolumn{10}{|c|}{ Angle malocclusion classification } \\
\hline & \multicolumn{2}{|c|}{ Class 1} & \multicolumn{2}{|c|}{ Class 2 div 1} & \multicolumn{2}{|c|}{ Class 2 div 2} & \multicolumn{2}{|c|}{ Class 3} & \multicolumn{2}{|c|}{ Total } \\
\hline & $n$ & $\%$ & $\mathbf{n}$ & $\%$ & $n$ & $\%$ & $\mathbf{n}$ & $\%$ & n & $\%$ \\
\hline Female & 168 & 55.8 & 72 & 23.9 & 41 & 13.6 & 20 & 25.8 & 301 & 56.4 \\
\hline Male & 126 & 54.1 & 51 & 21.9 & 32 & 13.7 & 24 & 13.5 & 233 & 43.6 \\
\hline Total & 294 & 55.1 & 123 & 23 & 73 & 13.7 & 44 & 8.2 & 534 & 100 \\
\hline
\end{tabular}

Table 2. The relationship between malocclusion classification and mean decay, missing, filled teeth scores

\begin{tabular}{|l|l|l|l|l|}
\hline Malocclusion classification & $\mathbf{n}$ & Mean DMFT & Standard deviation & Standard error \\
\hline Class 1 & 294 & $4.510^{\mathrm{a}}$ & 3.0999 & 0.1808 \\
Class 2 div 1 & 123 & $4.407^{\mathrm{ab}}$ & 3.2538 & 0.2934 \\
Class 2 div 2 & 73 & $3.274^{\mathrm{b}}$ & 2.6628 & 0.3117 \\
Class 3 & 44 & $4.523^{\mathrm{a}}$ & 3.5666 & 0.5377 \\
Total & 534 & 4.318 & 3.1408 & 0.1359 \\
\hline DMFT: Decay, missing, filled teeth, div: Division \\
\hline
\end{tabular}

\begin{tabular}{|c|c|c|c|c|c|c|c|c|c|}
\hline \multirow{3}{*}{ Anterior segment crowding } & \multicolumn{9}{|c|}{ The community periodontal index of treatment needs (CPITN) } \\
\hline & \multicolumn{2}{|c|}{ CPITN 0} & \multicolumn{2}{|c|}{ CPITN 1} & \multicolumn{2}{|c|}{ CPITN 2} & \multicolumn{2}{|c|}{ Total } & \multirow{2}{*}{$x^{2}$} \\
\hline & $\mathbf{n}$ & $\%$ & n & $\%$ & $\mathbf{n}$ & $\%$ & n & $\%$ & \\
\hline 0 & 79 & 59.4 & 140 & 39.1 & 15 & 34.9 & 234 & 43.8 & \multirow{4}{*}{22.114} \\
\hline 1 & 28 & 21.1 & 100 & 27.9 & 8 & 18.6 & 136 & 25.5 & \\
\hline 2 & 26 & 19.5 & 118 & 33 & 20 & 46.5 & 164 & 30.7 & \\
\hline Total & 133 & 24.9 & 358 & 67 & 43 & 8.1 & 534 & 100 & \\
\hline
\end{tabular}




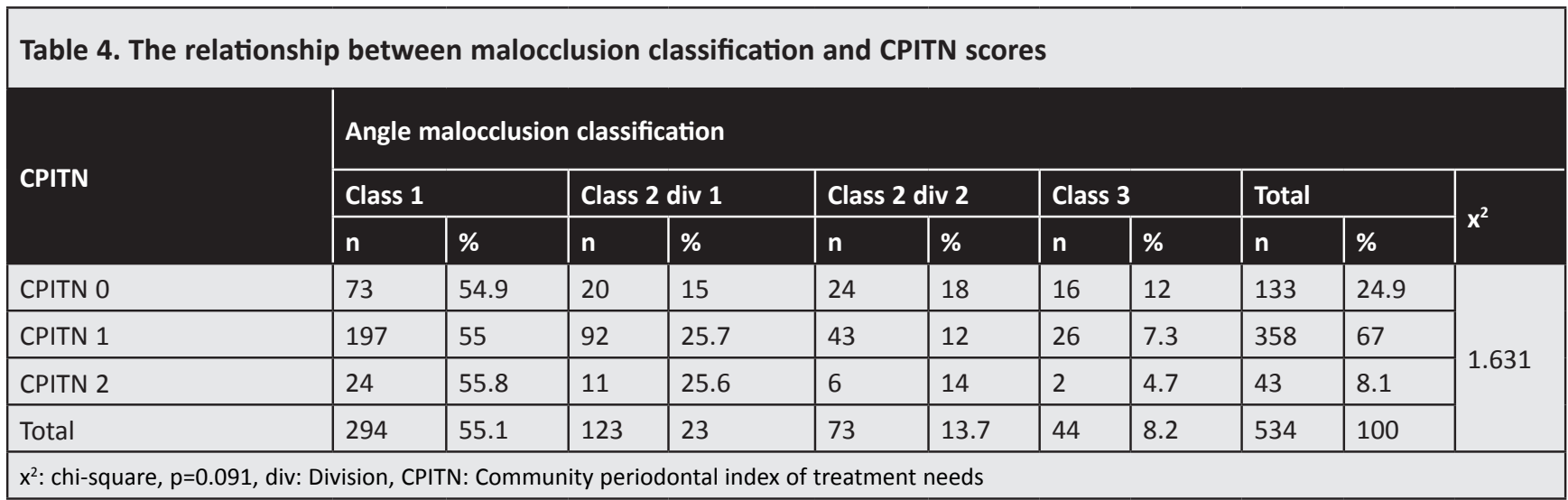

\section{Discussion}

This cross-sectional study was conducted in 12-14-year-old children. Because, the eruption of permanent teeth completes nearly at the age of 13 and the clinical diagnosis of the type and extent of malocclusion is best made at this age group (17). Also, In a study, when the patients who applied to the clinic for orthodontic treatment were compared according to their dentition periods (6-9, $10-12$ and $\geq 13$ years), it was observed that the most frequent patients were 13 years (19). Because of these reasons, we decided to evaluate the relationship between malocclusion and related various factors in children aged 12-14 years.

One of the methods widely used in epidemiological studies of malocclusions is Angle's malocclusion classification (20). In our study, according to Angle's classification, $55.1 \%$ of children had class 1 malocclusion; this result was similar to that of a study performed with 100 children (10-12 years of age) in Turkey (21). However, recent studies have shown that the most common malocclusion in adolescents is class 2 malocclusion in Turkey (22-25). Nevertheless, when the literature review was done, data on the prevalence of malocclusion are limited (26-28).

Since socio-economic differences are an important factor in Turkey, families were separated into groups according to monthly income levels, and their effects on malocclusion were examined in our study. Some studies have reported that children at low socioeconomic levels have more severe malocclusions and poor oral/dental health $(20,29,30)$. However, there are also studies that have reported that the severity and classification of malocclusion are not different based on socio-economic status (31-33). In our study, there was no statistically significant relationship between the socio-economic levels and malocclusion classification of children reform of the health care systems to provide government-subsidized treatment according to the past years has made it easier for the low-income families to benefit protective and preventive dental programs in early dentition period of their children from the public hospitals. Thus, this could contribute the prevention of malocclusion in children. If an identical study is repeated in a few years after changes to the socio-economic environment in the overall population, different results might be observed. One of the etiologic factors that can cause the space loss in the dental arch and malocclusions, both in the mixed and permanent dentition, is dental caries (31-33). Children with dental caries (DMFT $>0$ ) were almost twice as likely to have class 2-3 malocclusion compared with children without dental caries (DMFT=0) (8). On the other hand, in a study of 12-year-old children in India in 2015, no association was found between malocclusion and caries (9). In our study, the differences between mean DMFT scores and malocclusion classification were not statistically significant $(p>0.05)$. Because, the DMFT index is inadequate when compares dental caries and malocclusion. It does not distinguish between a small, non-cavitated lesion and a large cavitated lesion with loss of tooth structure. It includes many lesions that are non-cavited and therefore can have no more effect on malocclusion. Individuals with a moderate and high risk for caries have increased the orthodontic treatment needs (34). Indeed, according to Dental Health Component, children with high DMFT scores 
have increased orthodontic treatment needs $(35,36)$. According to Dental Aesthetic Index (DAI), children between the ages of 11 and 15 with a DAl score of $>35$ were reported to have more dental caries than other children (37). The prevalence of severe caries (DMFT $>8$ ) was observed to increase from $10.8 \%$ to $50 \%$ when DAl scores were increased (38). The early prevention and treatment of caries will help to reduce orthodontic treatment needs.

Malocclusion is also an important factor in the etiology of periodontal disease. Irregularities in the lower anterior teeth can have adverse effects on the periodontal health of the teeth, increase plaque accumulation, and lead to periodontal diseases (39). Gingivitis was observed to be at a high level in patients with malocclusion compared with those without malocclusion (40). Conversely, in a study of children with a mean age of $12.38 \pm 0.75$, there was no correlation between periodontal disease and irregularities of the teeth when oral hygiene was good (41). In another study of children aged 10-18 years, malocclusion severity was not associated with periodontal status between groups with an overjet of more than $6 \mathrm{~mm}$, a deep bite of more than $6 \mathrm{~mm}$, and posterior unilateral or bilateral crossbite (42). Similar to the results of these studies, there was no statistically significant relationship between CPITN scores and malocclusion classification in our study ( $p>0.05)$. Due to differences between the sample groups and the methods used, different results could be obtained when evaluating the relationship between periodontal status and malocclusion. In addition, it is possible that the CPITN measures the periodontal treatment needs of the entire jaw and masks local periodontal problems with healthy areas (10).

When the relationship between treatment needs and oral hygiene conditions (plaque, amount of calculus, gingivitis, and pocket depth) was assessed, no relationship was found $(43,44)$. In a study in Nigeria, the association between the DAI and CPITN scores of patients with a mean age of $15.8 \pm 7.5$ was not statistically significant (45). In contrast, a study in Turkey involving 836 patients between 11 and 14 years of age has reported a close relationship between treatment priority index TPI and CPITN scores (10).

Occlusal irregularities and crowding may be responsible for periodontal diseases (46). Although there was a correlation between irregularity and gingivitis scores, the amount of plaque accumulation and the degree of irregularity were not clinically significant (43). Studies have reported a correlation of malpositions in the lower arch, irregularities in the upper arch, and deep bite with CPITN scores $(14,47)$. For teeth with occlusal irregularities, there was a significant increase in the depth of scaling every year; however, there was no significant increase in scaling depth for teeth without occlusal irregularities (48).

In this study, only $6.4 \%$ of the patients without anterior segment crowding had a CPITN score of 2. CPITN 0 scores were decreased with increasing crowding in the anterior segment. The positive relationship between the degree of irregularity and the severity of gingival inflammation may be attributed to the bad oral hygiene of the patients, which can lead to dental plaque formation and cause the onset of periodontal inflammation. Nevertheless, crowding would not contribute to gingivitis if the individual has good oral hygiene (46).

\section{Conclusion}

In the study, periodontal status was associated with anterior segment crowding but not malocclusion classification. However, malocclusion could cause an increase in plaque retention. In addition, it was concluded from the present study that malocclusion had no significant effect on dental caries and parental socio-economic status. Thus, the hypothesis of the present study was rejected.

Patients with malocclusion should be evaluated so as to facilitate oral health by minimizing inaccessible areas in the oral cavity. Assessment of the orthodontic treatment needs of children should be based not only on the severity of malocclusion features but also on the dentition period, and the age group of the children. Further studies involving large populations are necessary in different age groups, which requires increased attention regarding to prevent maloclussion.

\section{Ethics}

Ethics Committee Approval: Süleyman Demirel University Faculty of Medicine Clinical Studies Ethics Council (approval number: 2014/93).

Informed Consent: All patients included were informed about the study.

Peer-review: Externally and internally peerreviewed. 


\section{Authorship Contributions}

Surgical and Medical Practices: E.Ö., Concept: E.Ö., Ç.K., Design: E.Ö., Ç.K., Data Collection or Processing: E.Ö., Analysis or Interpretation: E.Ö., Literature Search: E.Ö., Writing: E.Ö., Ç.K.

Conflict of Interest: No conflict of interest was declared by the authors.

Financial Disclosure: The authors declared that this study received no financial support.

\section{References}

1. Batool I, Zaidi AA, Alı Rızvı SA. Perıodontal evaluation of afid cadets ın lower anterıor crowdıng. Pakıstan Oral\&Dental Journal 2007; 27: 53-60.

2. Frazao $P$, Narvai PC. Socio-environmental factors associated with dental occlusion in adolescents. Am J Orthod Dentofacial Orthop 2006; 129: 809-16.

3. Prabu D, Naseem B, Manish J, Mathur A, Dhanni C, Saify M, et al. A relationship between socio-economic status and orthodontic treatment need. Virtual J Orthod 2008; 8: 1-7.

4. Almeida AB, Leite IC, Melgaço CA, Marques LS. Dissatisfaction with dentofacial appearance and the normative need for orthodontic treatment: determinant factors. Dental Press J Orthod 2014; 19: 120-6.

5. Badran SA, Sabrah AH, Hadidi SA, Al-Khateeb S. Effect of socioeconomic status on normative and perceived orthodontic treatment need. Angle Orthod 2014; 84: 588-93.

6. Dzemidzic V, Tiro A, Redzepagic-Vrazalica L, Nakas E. The need for orthodontic treatment among 12-14 years old Bosnian schoolchildren. Acta Stomatol Croat 2012; 46: 105-10.

7. Abdulwahab B. Lower arch crowding in relation to periodontal disease. MJD 2008; 5: 154-8.

8. Mtaya M, Brudvik P, Astrøm AN. Prevalence of malocclusion and its relationship with socio-demographic factors, dental caries, and oral hygiene in 12 to 14 year old Tanzanian school children. Eur J Orthod 2009; 31: 467-76.

9. Arora G, Bhateja S. Prevalence of dental caries, periodontitis, and oral hygiene status among 12-year-old schoolchildren having normal occlusion and malocclusion in Mathura city: A comparative epidemiological study. IJDR 2015; 26: 48-52.

10. Nalcacı R, Demirer S, Ozturk F, Altan BA, Sokucu O, Bostanci $V$. The relationship of orthodontic treatment need with periodontal status, dental caries, and sociodemographic factors. The Scientific World J 2012; 2012: 498012.

11. Nuca C, Amariei C, Badea V, Jipa I. Relationships between Constanta (Romania) 12-year-old children's oral health status and their parents' socioeconomic status, oral health knowledge and attitudes. OHDMBSC 2009; 8: 44-52.

12. Vedovello SA, Ambrosano GM, Pereira AC, Valdrighi HC, Filho MV, Meneghim Mde C. Association between malocclusion and the contextual factors of quality of life and socioeconomic status. Am J Orthod Dentofacial Orthop 2016; 150: 58-63.
13. Abuaffan AH, Salih SA. Malaligned Teeth and Periodontal Health in the Anterior Segment among a Sample of Sudanese Patients. PJDOH 2015; 1: 13-23.

14. Pugaca J, Urtane I, Liepa A, Laurina Z. The relationship between the severity of malposition of the frontal teeth and periodontal health in age 15-21 and 35-44. SBDMJ 2007; 9: 86-90.

15. Klein H, Palmer CE, Knutson JW. Studies on dental caries: I. Dental status and dental needs of elementary school children. Public Health Rep 1938; 53: 751-65.

16. Angle EH. Classification of malocclusion. Dent Cosmos 1899; 41: 248-64.

17. WHO (1997). Health Surveys. Basic Methods. Ed. 3 Geneve: World Health Organization.

18. Ainamo J, Barmes D, Beagrie G, Cutress T, Martin J, SardoInfirri J. Development of the World Health Organization (WHO) community periodontal index of treatment needs (CPITN). Int Dent J 1982; 32: 281-91.

19. Aksoy A. Illk pılot ağız diş hastalıkları hastanesi ortodonti bölümüne başvuran hastaların sosyo-ekonomik profili. S.D.Ü Tıp Fak Derg 2005; 12: 38-45.

20. Rauten AM, Olteanu M, Maglaviceanu C, Popescu MR, Teodorescu E, Surlin P. Malocclusions assessment in a group of Romanian school children with different socio-economic status. Intern J Med Dent 2014; 4: 181-8.

21. Koruyucu $M$, İnce EBT, Münevveroğlu AP, Acar G, Seymen F. Orthodontic treatment needs of children: comparıson of three Index. JIUFD 2014; 48: 1-12.

22. Gelgör IE, Karaman Ai, Ercan E. Prevalence of Malocclusion Among Adolescents In Central Anatolia. Eur J Dent 2007; 1: 12531.

23. Öztoprak M, İşman N, Tozlu M, Durduran S, Arun T. Ortodontik tedavi ihtiyacı olan hastaların coğrafik bilgilendirme sistemi ile bölgelere göre dağılımının incelenmesi. 7tepeklinik 2011; 3: 316.

24. Oden F, Bekar E, Bıcakcı AA. Evaluation of malocclusion and crowding in under orthodontic treatment. Cumhuriyet Dent J 2015; 18: 257-64.

25. Bilgic F, Gelgor IE, Celebi AA. Malocclusion prevalence and orthodontic treatment need in central Anatolian adolescents compared to European and other nations' adolescents. Dental Press J Orthod 2015; 20: 75-81.

26. Daragiu DE, Ghergic DL. Correlation between malocclusion-oral habits and socio-economic factors. Studia Universitatis Vasile Goldis Arad. Seria Stiintele Vietii 2012; 22: 149-54.

27. Hanna A, Chaaya M, Moukarzel C, El Asmar K, Jaffa M, Ghafari JG. Malocclusion in elementary school children in Beirut: Severity and related social/behavioral factors. Int J Dent 2015; 2015: 351231.

28. Marques LS, Barbosa CC, Ramos-Jorge ML, Pordeus IA, Paiva $\mathrm{SM}$. Malocclusion prevalence and orthodontic treatment need in 10-14-year-old schoolchildren in Belo Horizonte, Minas Gerais State, Brazial: a psychosocial focus. Cad Saude Publica 2005; 21 : 1099-106. 
29. Bernabe E, Flores-Mir C. Normative and self-perceived orthodontic treatment need of a Peruvian university population. Head Face Med 2006; 2: 1-8.

30. Doğan AA, Sari $E$, Uskun $E$, Sağlam AM. Comparison of orthodontic treatment need by professionals and parents with different socio-demographic characteristics. Eur J Orthod 2010; 32: 672-6.

31. Stahl F, Grabowski R. Orthodontic findings in the deciduous and early mixed dentition - inferences for a preventive strategy. J Orofac Orthop 2003; 64: 401-16.

32. Caplin JL, Evans CA, Begole EA. The relationship between caries and malocclusion in Chinese migrant workers' children in Shanghai. Chin J Dent Res 2015; 18: 103-10.

33. Gaikwad SS, Gheware A, Kamatagi L, Pasumarthy S, Pawar V, Fatangare $M$. Dental caries and its relationship to malocclusion in permanent dentition among 12-15 year old school going children. J Int Oral Health 2014; 6: 27-30.

34. Kumar CP, Londhe SM, Kotwal A, Mitra R. Prevalence of malocclusion and orthodontic treatment need in schoolchildren - An epidemiological study. Med J Armed Forces India 2013; 69: 369-74.

35. Nobile CG, Pavia M, Fortunato L, Angelillo IF. Prevalence and factors related to malocclusion and orthodontic treatment need in children and adolescents in Italy. Eur J Public Health 2007; 17: 637-41.

36. Abbas A, Syed IB, Abbas H, Malık F. Prevalence of malocclusion and its relationship with dental caries in a sample of Pakıstanı school children. Pakistan Oral\&Dental Journal 2015; 35: 216-9.

37. Baskaradoss JK, Geevarghese A, Roger C, Thaliath A. Prevalence of malocclusion and its relationship with caries among school children aged $11-15$ years in Southern India. Korean J Orthod 2013; 43: 35-41.

38. Borzabadi-Farahani A, Borzabadi-Farahani A. Agreement between the index of, complexity, outcome, and need and the dental and aesthetic components of the index of orthodontic treatment need. Am J Orthod Dentofacial Orthop 2011; 140: 233-8.

39. Gökçelik A, Polat Ö. Ortodontik tedavilerin periodontal dokular ve diş çürükleri üzerine etkileri. Cumhuriyet Üni. Diş Hek. Fak. Derg 2006; 9: 118-26.

40. Addy M, Griffiths GS, Dummer PM, Kingdon A, Hicks R, Hunter $M L$, et al. The association between tooth irregularity and plaque accumulation, gingivitis, and caries in 11-12-year-old children. Eur J Orthod 1988; 10: 76-8.

41. Abu Alhaija ESJ, Al-Nimri KS. Al-Khateeb SN. Orthodontic treatment need and demand in 12-14 year-old Jordanian school children. Eur J Orthod 2004; 26: 261-3.

42. Torres H, Correa DS, Zenobio EG. Periodontal evaluation of patients between 10 and 18 years with different malocclusion. Rev Dent Press Ortod Ortop Facial 2006; 11: 73-80.

43. Buckley LA. The relationship between malocclusion and periodontal disease. J Periodontol 1972; 43: 415-7.

44. Katz RV. An epidemiologic study of the relationship between various states of occlusion and the pathological conditions of dental caries and periodontal disease. J Dent Res 1978; 57: 433-9.

45. Onyeaso CO, Arowojolu MO, Taiwo JO. Periodontal status of orthodontic patients and the relationship between dental aesthetic index and community periodontal index of treatment need. Am J Orthod Dentofacial Orthop 2003; 124: 714-20.

46. Souza Schroeder MD, Ulema Rıbeıro GL. Evaluation of periodontal index of gingival and plaque with dental crowding in development of gingivits in children and adolescents. RSBO 2004; 1: 17-21.

47. Ngom PI, Benoist HM, Thiam F, Diagne F, Diallo PD. Influence of orthodontic anomalies on periodontal condition. Odontostomatol Trop 2007; 30: 9-16.

48. Harrel SK, Nunn ME. The effect of occlusal discrepancies of periodontitis. II. Relationship of occlusal treatment to the progression of periodontal disease. J Periodontal 2001; 72: 495505. 